Japan. J. Med. Sci. Biol., 36, 55-57, 1983

Epidemiological Report

\title{
DETECTION OF ANTIBODY AGAINST HEMORRHAGIC FEVER WITH RENAL SYNDROME (HFRS) VIRUS IN SERA OF HOUSE RATS CAPTURED IN PORT AREAS OF JAPAN
}

\author{
Chimaru MORITA, Kazuyoshi SUGIYAMA ${ }^{1}$, Yoshiharu MATSUURA, \\ TAKashi KITAMURA ${ }^{1}$, Toshihiko KOMATSU1, YoriYuki AKAO², \\ WATARU JITSUKAWA ${ }^{3}$ and HISAO SAKAKIBARA ${ }^{4}$ \\ Department of Veterinary Science, ${ }^{1}$ Department of Enteroviruses, and ${ }^{2}$ Central Virus \\ Diagnostic Laboratory, National Institute of Health, Musashimurayama, \\ Tokyo 190-12, '3okohama Quarantine Station, Yokohama, \\ and ${ }^{4}$ Kobe Quarantine Station, Kobe
}

(Received October 1, 1982. Accepted October 26, 1982)

Three types of hemorrhagic fever with renal syndrome (HFRS), i.e., urban, rural and laboratory types, have been observed in Japan (Tamura, Yatsukura and Okano, 1979; Kawamata, 1981; Umenai et al., 1979). The laboratory-type outbreaks were exclusively associated with laboratory rats (Umenai et al., 1979) and the rural type was suspected of Microtus or Apodemus-borne (Umenai et al., 1981).

An urban-type outbreak with more than 100 cases of HFRS occurred from 1960 to 1972 in the central area of Osaka City where there were no wild Microtus or Apodemus species (Lee et al., 1979). Nevertheless, house rats were assumed to be the reservoir without any further epizootical survey. Recently, a mildtype infection in urban areas in China was related to house rats (Xu et al., 1982; Hang et al., 1982). In adition, house rats captured in port areas in the United States, i.e., New Orleans, Philadelphia and Houston, were found to have antibody against Hantaan virus (Tsai et al., 1982; LeDuc et al., 1982).

The sera of house rats ( $R$. norvegicus and $R$. rattus) collected in the port areas of Kobe and Yokohama during the period from 1978 to 1980 were examined by the indirect fluorescent antibody (IFA) method described previously (Kitamura et al., 1983). The antigen preparations used were smears of VERO-E6 cells infected with SR-11 strain HFRS virus at the 7th passage in these cells after

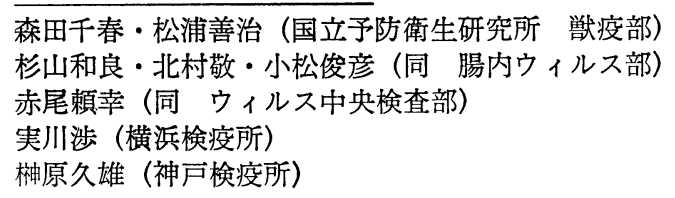


TABLE I

Indirect fluorescent antibody among house rats from Kobe and Yokohama 1978-1980

\begin{tabular}{lccccc}
\hline Port & Year & \multicolumn{2}{c}{$\begin{array}{c}\text { Number } \\
\text { Positive* }\end{array}$} & $\begin{array}{c}\text { Number } \\
\text { tested }\end{array}$ & Titer \\
\hline Kobe & 1978 & 2 & $/$ & 168 & $64-128$ \\
& 1979 & 5 & $/$ & 129 & $64-128$ \\
subtotal & 1980 & 0 & $/$ & 19 & \\
Yokohama & 1978 & 7 & $/$ & 316 & \\
& 1979 & 1 & $/$ & 33 & 4,096 \\
& 1980 & 0 & $/$ & 6 & 2,048 \\
subtotal & & 2 & $/$ & 81 & \\
Total & & 9 & $/$ & 397 & \\
\hline
\end{tabular}

* IFA titer higher than 1:64.

isolation from the lung tissue of an experimental rat related to the outbreak in Sapporo Medical College (Kitamura et al., 1983). The antigen smears were overlaid with 1:10 diluted serum in the screening test. Serial twofold dilutions made from 1:16 dilutions of tentatively positive sera were examined. When the IFA endpoint titer of a serum was higher than 1:64, the serum was considered as positive of antibody against HFRS virus.

The antibody to HFRS virus was found in six of $318 R$. norvegicus and three of $79 R$. rattus sera. Seven of 316 sera from the port of Kobe and two of 81 sera from Yokohama revealed positive HFRS virus antibody. The ratios of positive sera in 1978,1979 and 1980 were $1.5 \%, 3.5 \%$ and $0 \%$, respectively (Table I).

In Houston, USA, five of 92 sera were found to be positive. All five positive sera were collected from the same site (LeDuc et al., 1982). Focal condensation of HFRS virus-infected rats observed was suggested from the fact that three of five positive rats from the port of Kobe in 1979 were captured on the same wharf.

Since the present survey was limited to the rats from the port areas, the question of whether the distribution of antibody-positive rats was restricted to the port areas or found also in rat population in other inland areas was not clarified.

The incidence of HFRS among human population has not been recorded in port areas or urban areas in Japan since 1972. There may be one possibility that the antibody detected in rats is against another virus closely related and antigenically cross-reactive to HFRS virus.

Further investigations should be made on the ecology of HFRS-associated virus among wild rodents and human beings.

\section{ACKNowledgement}

Sera were collected by the technical staff of Yokohama and Kobe Quarantine Stations. Techni- 
cal assistance by Miss M. Ogata of National Institute of Health in processing the specimens is appreciated.

The present study was supported in part by a Scientific Research Grant (1982) from the Ministry of Health and Welfare, Japanese Government.

\section{REFERENCES}

Hang, C. S., Song, G., QIu, X. Z., Du, Y. L., Zhao, J. N., Kong, B. X. GaO, G. Z. and Lian, H. X. (1982): Etiological study of outbreaks of a mild type of hemorrhagic fever. Chin. J. Epidemiol., 3, 204-205 (in Chinese).

Kawamata, J. (1981): Studies on the surveillance and control measures of zoonoses associated with animal experimentation in special reference to the hemorrhagic fever. A report to the Ministry of Education, Science and Culture (in Japanese).

Kitamura, K., Morita, C., Komatsu, T., Sugiyama, K., Arikawa, J., Shiga, S., Takeda, H., Akao, Y., Imaizumi, K., OYA, A., Hashimoto, N. AND URAsawa, S. (1983): Isolation of virus causing hemorrhagic fever with renal syndrome (HFRS) through a cell culture system. Japan. J. Med. Sci. Biol., 36, 17-25.

LeDuc, J. W., Smith, G. A., Bagley, L. R., Hasty, S. E. And Johnson, K. M. (1982): Preliminary evidence that Hantaan or closely related virus is enzootic in domestic rodents. New Engl. J. Med., 307, 624.

Lee, H. W., Lee, P. W., Tamura, M., Tamura, T. and Okuno, Y. (1979): Etiological relation between Korean hemorrhagic fever and epidemic hemorrhagic fever in Japan. Biken J., 22, 41-45.

Tamura, T., Yatsukura, T. and Okuno, K. (1979): Clinical features of epidemic hemorrhagic fever. Kansen, Ensho, Men-eki (Infection, Inflammation and Immunity), 9, 280-289 (in Japanese).

Tsai, T. F., Bauer, S. P., Sasso, D. R., McCormick, J. B., Bradford, H., Caraway, C. T., McFarland, L. M., Medrand, O. ANd Soulie, G. (1982): Preliminary evidence that Hantaan or a closely related virus is enzootic in domestic rodents. New Engl. J. Med., 307, 623-624.

Umenai, T., Lee, H. W., Lee, P. W., Saito, T., Hongo, M., Hashinaga, K., Nobunaga, T., HoRIUCHI, T. AND IshIDA, N. (1979): Korean hemorrhagic fever in staff in animal laboratory. Lancet, $i$, 1314-1316.

Umenai, T., Watanabe, M., Sekino, H., Yokoyama, S., Kaburagi, T., Takahashi, T., Lee, H. W. AND IsHidA, N. (1980): Korean hemorrhagic fever among rural residents in Japan. J. Infect. Dis., 144, 460-463.

Xu, G. W., Zi, C. Q., Ma., Z. T., Meng, Y. S., Wang, S. J., AN, M. J. and Zhang, X. Q. (1982): Epidemiological study of an outbreak of a mild type of hemorrhagic fever. Chin. J. Epidemiol., 3, (in Chinese) (to be published). 